\title{
Da der gik kirkepolitik i Genforeningen
}

\section{af Per Ingesman}

Før 1920 var der store forskelle på den kirkelige administration nord og syd for Kongeåen. Blandt andet havde man i Slesvig-Holsten en egentlig kirkeforfatning, mens noget lignende savnedes i Danmark. Genforeningen pustede derfor nyt liv i de kongerigske ønsker om at opnå en kirkeforfatning også i Danmark, og kirkeforfatningsspørgsmålet kom til at spille en vigtig rolle $\mathrm{i}$ de forhandlinger om Nordslesvigs kommende plads inden for den danske folkekirke, der stod på fra indgåelsen af våbenhvilen i 1918 til vedtagelsen af kirkelovene af 1922. Forskningsstipendiat, lic. theol. Per Ingesman, Århus, kaster her lys over denne hidtil ukendte side af genforeningshistorien.

\section{Indledning}

Det er velkendt, at der gik politik i Genforeningen - at det, der skulle have været den store manifestation af nationalt sammenhold og glæde, på grund af uenigheden om grænsedragningen udartede til en bitter politisk strid, der har sat sig spor i sønderjysk politik frem til i dag.

Mindre kendt er det, at der også gik kirkepolitik i Genforeningen. Ikke så meget i Sønderjylland selv, for her var der i virkeligheden ingen grundlæggende uenighed om, hvordan den kirkelige genforening med Danmark skulle finde sted, men derimod i Danmark. Det hænger sammen med, at de to vigtigste af den kirkelige genforenings mange problemer, nemlig kirkens økonomi og dens styre, berørte aktuelle og meget ømtålelige kirkepolitiske spørgsmål i datidens Danmark.

Hvad økonomien angår, var det spørgsmålet om statens ejendomsret til kirkegodset, der satte sindene i bevægelse: Netop i 1919 havde den radikale regering som led i de store jordlove, der skulle skaffe jord til oprettelsen af statshusmandsbrug, foretaget en inddragelse af de bortforpagtede præstegårdsjorder. Men tillige indgik kirkens økonomi sammen med dens styre i det, man kalder det kirkelige forfatningsspørgsmål, altså spørgsmålet, om folkekirken uden at adskilles fra staten og blive en egentlig frikirke skulle have et lovfæstet selvstyre med ret til både at ordne sine egne »indre anliggender« uden statslig indblanding og til at medvirke ved statslige lovgivningsarbejder på det kirkelige område. Også dét var et varmt emne, senest aktualiseret $\mathbf{i}$ den berømte Arboe Rasmussen-sag (1911-17), hvor den radikale kirkeministers indgriben i 


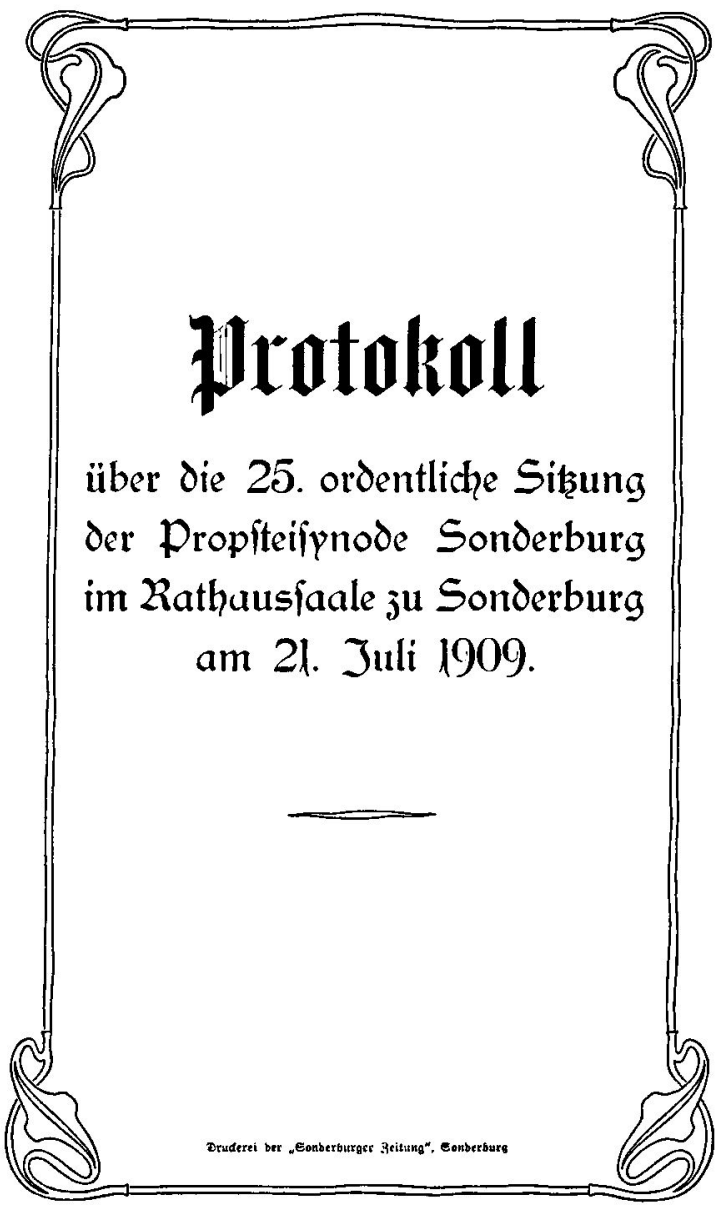

Her ses den trykte forhandlingsprotokol for provstisynoden $i$ Sonderborg 1909. Efter Projsens overtagelse af hertugdommerne $i$ 1864 fik den slesvig-holstenske landskirke lov at bestå som en selvstandig kirke. Den overste kirkelige myndighed var Kultusministeriet i Berlin, men det centrale forvaltningsorgan var konsistoriet i Kiel. På lokalt plan varetoges kirkestyret af provsterne $i$ de enkelte provstier - hvoraf der fandtes fem i Nordslesvig: Haderslev, Aabenraa, Sonderborg, Torninglen og Tonder - og af sogneprasterne. I kirkestyret deltog de menighedsreprasentationer, der blev skabt ved den synodale kirkeforfatning of 1876 : kirkekollegier og kirkeforstanderskaber i sognene, provstisynoder og provstisynodeudvalg $i$ provstierne og en fallessynode for hele kirken; sidstnovnte samledes $i$ Rendsborg, som regel hvert tredje ar, og reprasenteredes ellers af et stående fallessynodeudvalg.

et udpræget læremæssigt spørgsmål havde vakt voldsom harme i kirkelige kredse og givet tilhængerne af en kirkeforfatning ny vind i sejlene. ${ }^{1}$

Kirken i Sønderjylland havde siden middelalderen gennemløbet sin egen udvikling, ofte i snævrere tilknytning til tysk end til dansk kirkeliv, og på talrige punkter var der afgørende forskelle på forholdene i Hertugdømmet og i Kongeriget. Det gælder ikke mindst på de to områder, der her er tale om, økonomi og kirkestyre.

På det økonomiske område var forskellen mellem de kongerigske og de sønderjyske forhold af gammel dato. I Kongeriget havde staten siden reformationen i 1536 betragtet sig som ejer af kirkegodset, med ret til frit at disponere over det, blot den opfyldte forpligtelsen til at understøtte kirken økonomisk. 
I Sønderjylland derimod var kirkegodset gennem alle historiske omskiftelser forblevet noget, der tilhørte kirken selv og derfor var underlagt de lokale menigheders disposition. ${ }^{2}$

Hvad kirkens styre angik, beroede forskellene især på, at der, både i Danmark og i Sønderjylland, var vedtaget gennemgribende nyordninger efter adskillelsen i 1864. Den sønderjyske kirke kendte intet til den lovgivning, der var blevet indført i den danske folkekirke som følge af de folkelige vækkelsesbevægelser: først de såkaldte »frihedslove«, der allerede i anden halvdel af det 19. århundrede løsnede statskirkens snærende bånd, siden menighedsrådsloven, hvormed der efter Systemskiftet i 1901 skete en demokratisering af kirken. ${ }^{3}$ Omvendt havde kirken i Sønderjylland i den prøjsiske tid (1876) fået en forfatning med repræsentative organer, som man ikke kendte i Danmark, dels synoder $\mathrm{i}$ hvert enkelt provsti, dels en stor fællessynode for hele den slesvig-holstenske landskirke. På sogneplan havde denne slesvig-holstenske kirkeforfatning indført direkte valgte kirkekollegier på 12-30 medlemmer, der igen valgte kirkeforstanderskaber bestående af 4-10 kirkeældste med præsten som født formand. $^{4}$

Selv om kirkeforstanderskaberne på flere måder kan paralleliseres med menighedsrådene, var der betydelige forskelle. Først og fremmest havde de sønderjyske kirkeforstanderskaber ikke den afgørende indflydelse på præstevalget, som de danske menighedsråd havde fået. ${ }^{5}$ Omvendt kendte man i Danmark intet til det udstrakte selvstyre på det økonomiske område, som de lokale menigheder havde i Sønderjylland, hvor det var kirkeforstanderskabet, der behandlede de fleste sager vedrørende menigheden og dens kirke, herunder varetog administrationen af sognets to $»$ kasser«, kirkekassen og præstelønningskassen. En ikke uvigtig forskel var i øvrigt, at kun mænd havde valgret til de sønderjyske kirkeforstanderskaber, mens den danske menighedsrådslovgivning gav valgret også til kvinder.

Sønderjyderne var grundlæggende enige om, at der $i k k e$ efter Genforeningen skulle eksistere en særlig sønderjysk kirke ved siden af folkekirken. Der skulle også i kirkelig henseende ske en fuldstændig genforening, således at den »unaturlige« grænse ved Kongeåen slettedes »lempeligt, men grundigt « ${ }^{6}$ Den holdning rejste en række spørgsmål, da man efter våbenhvilen i november 1918 begyndte at forberede Genforeningen fra sønderjysk hold: Hvordan skulle man forene den nordslesvigske kirke, der havde en forfatning, med en kirke som den danske folkekirke, der stod uden forfatning? Hvad skulle man stille op med de synodale forfatningsorganer, der var indført i Sønderjylland i den prøjsiske tid, og som var uden paralleller i folkekirken i Danmark? Skulle det sønderjyske kirkegods uden videre stilles til den danske stats disposition og lokalmenighederne give afkald på deres hævdvundne ret til at administrere 
deres egen økonomi? Og hvorledes skulle man i øvrigt forholde sig til de talrige detailspørgsmål, hvor der var forskel på de sønderjyske og de kongerigske kirkeforhold?

Der kunne sagtens skrives en hel bog om Nordslesvigs kirkelige genforening med Danmark. I denne artikel vil jeg nøjes med at behandle problemet om kirkens styre som det vigtigste af de mange og komplicerede spørgsmål, den kirkelige genforening rejste. ${ }^{7} \mathrm{Da}$ man fra sønderjysk side næsten med det samme foreslog, at de synodale forfatningsorganer fra prøjsertiden skulle afskaffes, kunne man tro, at enhver tale om kirkeforfatning i forbindelse med Genforeningen var taget af dagsordenen. Det var imidlertid ingenlunde tilfældet; faktisk kom kirkeforfatningsspørgsmålet til at spille en betydelig rolle i genforeningsprocessen. Især skyldes det ét bestemt ønske, som fremførtes fra sønderjysk hold vedrørende gennemførelsen af den kirkelige genforening: ønsket om nedsættelse af et særligt kirkeligt udvalg til forberedelse af den kommende fælles lovgivning for Danmark med Sønderjylland. Med dette ønske satte man fingeren på et centralt punkt $\mathrm{i}$ forholdet mellem kirke og stat i Danmark: spørgsmålet om Rigsdagens kompetence til at lovgive på det kirkelige område. Det er dette ønske, der står i fokus i det følgende, dels formuleringen af det i Sønderjylland, dels reaktionen på det i Danmark.

\section{Det sønderjyske ønske om et kirkeligt udvalg}

Forberedelserne til Nordslesvigs genforening med Danmark efter en kommende folkeafstemning begyndte umiddelbart efter, at der var sluttet våbenhvile i Første Verdenskrig i november 1918. De dansksindede sønderjyders politiske organisation, Vælgerforeningen for Nordslesvig, nedsatte en række udvalg på forskellige områder samt et specielt »aktionsudvalg«, der skulle koordinere hele arbejdet. Blandt de nedsatte udvalg var også et kirkeligt udvalg. ${ }^{8}$

Vælgerforeningens kirkelige udvalg holdt sit første egentlige forhandlingsmøde den 16. december 1918 og tog med det samme hul på de alvorlige spørgsmål. ${ }^{9}$ Første punkt på dagsordenen var "Den kirkelige Stilling i Almindelighed ved Overgangen til dansk Styre«. Under dette punkt gav udvalgets formand, gårdejer Mads Gram fra Københoved, en oversigt over menighedsrådsloven og andre forhold i den danske folkekirke. Udvalgets forhandlingsprotokol fortæller, at det skete »efter Oplysninger fra en Samtale med fhv. Kultusminister Appel, Askov«; Gram havde altså konsulteret selve ophavsmanden til den danske menighedsrådslov af 1912, Jacob Appel, der sad som forstander på Askov Højskole lige nord for grænsen. Næste punkt var spørgsmålet »Bør Nordslesvig beholde sin særlige Kirkeforfatning under den danske Folkekirke«. Her 
Sogneprast Hans Tonnesen, Hoptrup (1854-1935). Den slesvig-holstenske landskirke kendte ikke den frihedslovgivning, der gav de kirkelige retninger så gode muligheder $i$ den danske folkekirke, og grundtvigianerne $i$ Sonderjylland var derfor henvist til at danne frimenigheder. $P a ̊$ grund af det starke engagement $i$ det nationale sporgsmål udsattes deres frimenigheder for talrige chikanerier fra de tyske myndigheders side. Indre Mission holdt alle sine gudstjenester og moder pà dansk, men forsogte $i$ ovrigt at holde sig neutral $i$ nationalitetskampen. Fra dansk side sogte bl.a. H.P. Hanssen at trakke bevagelsen $i$ dansk retning, mens staten fra den anden side onskede, at Indre Mission der havde tilslutning fra knap en fjerdedel af Nordslesvigs praster skulle stille sig $i$ fortyskningens tjeneste. I 1912 revnede bevagelsen. "Det gamle Budskabs Indre-Mission “ brod ud og stillede sig mere åbenlyst på tysk side, mens kredsen omkring den mangearige formand Hans Tonnesen markerede sig starkere for den danske side. Foto: Institut for sonderjysk Lokalhistorie.

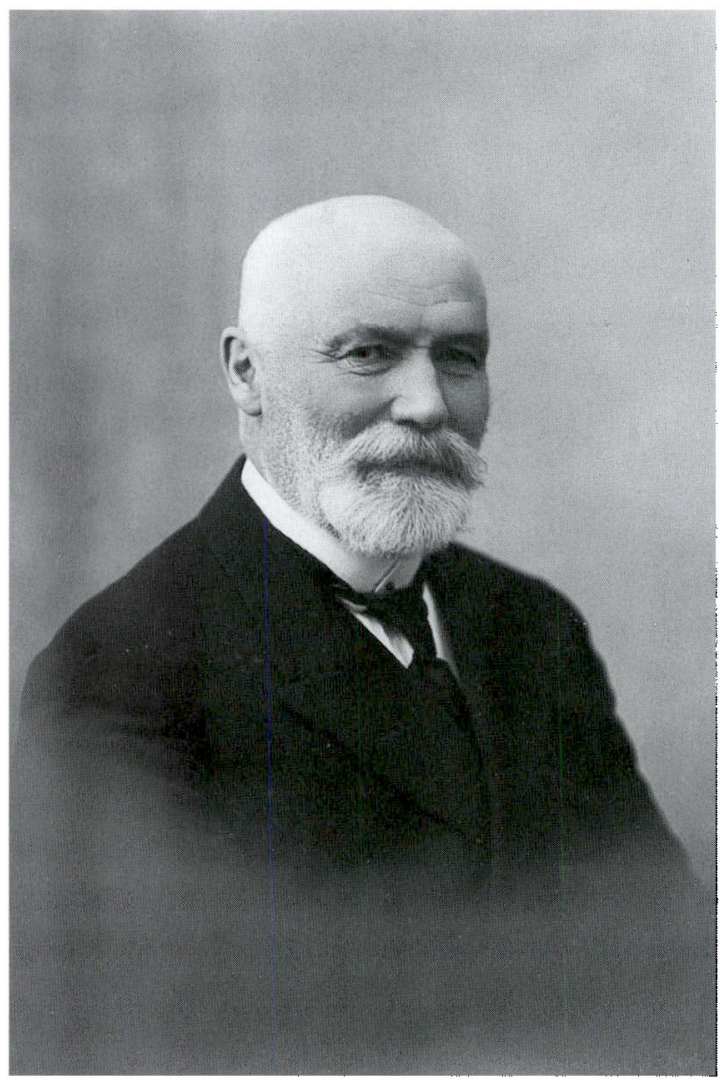

var det den mangeårige formand for Kirkelig Forening for Indre Mission $\mathrm{i}$ Nordslesvig, sognepræst Hans Tonnesen fra Hoptrup, der indledte med en redegørelse for udviklingen af den sønderjyske kirkeforfatning. Efter denne redegørelse vedtog man en af formanden foreslået udtalelse, ifølge hvilken sogneordningen - altså kirkekollegier og kirkeforstanderskaber - skulle bestå indtil videre, mens synodeordningen - provstisynoderne og fællessynoden - skulle afskaffes. Man bevægede sig således med det samme i retning af de danske forhold, hvor man som sagt kun havde repræsentation på sogneplan, i form af menighedsrådene, ingen organer på de højere niveauer. Til at udarbejde et mere detaljeret forslag nedsattes derefter et særligt underudvalg, forfatningsudvalget. Man anbefalede, at dette udvalg søgte samarbejde med »Udvalget for den nordslesvigske Kirkesag« i Danmark, en særlig organisation, som støt- 


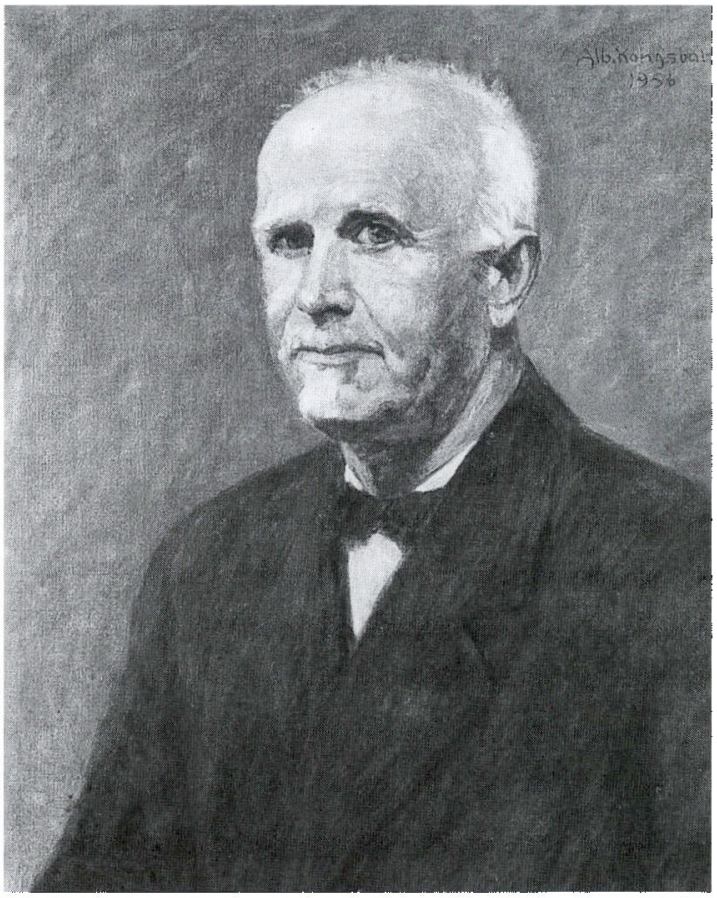

Gårdejer Mads Gram, Kobenhoved (1876-1952). Den 16. novermber 1918 nedsatte Valgerforeningen for Nordslesvig et udvalg til forberedelse af genforeningen på det kirkelige område. Alle kirkelige interesser inden for den nordslesvigske danskhed sogtes reprasenteret. De fem nordslesvigske prowsisynoder blev reprasenteret, og desuden kom udvalget til at bestå af lage medlemmer fra begge de to kirkelige retninger, grundtvigianismen og Indre Mission, og af reprasentanter for både sognepraster og frimenighedspraster. Af udvalgets 15 medlemmer var fire gejstlige. Formand blev Mads Gram, som horte til de grundtvigske medlemmer. Maleri på "Folkehjem « fra 1956. Foto: Institut for sonderjysk Lokalhistorie.

tede de grundtvigske frimenigheder i Sønderjylland, og hvori Jacob Appel igen spillede en rolle. ${ }^{10}$

På det følgende møde i det kirkelige udvalg (12. februar 1919) enedes man om et grundlæggende princip i hele det kirkelige udvalgs forslag: en tredeling af overgangstiden i 1) den første provisoriske forvaltningstid, 2) den lovordnede overgangstid og 3) den endelige sammensmeltning med den danske folkekirke. ${ }^{11}$ Et særligt underudvalg, der beskæftigede sig med kirkeformuen og de økonomiske problemer, "Finanskommissionen «, havde et forslag til ordningen af den sønderjyske kirkes økonomi under overgangen fra tysk til dansk styre klar, og forfatningsudvalget fremlagde sit tilsvarende forslag om ordningen af den sønderjyske kirkes administration i overgangsperioden. Det skete - som det oplyses i forhandlingsprotokollen - »efter en forudgaaet Forhandling i Frederits med Biskop Koch, Forstander Appel og flere kongerigske Præster«. Man havde således atter konsulteret folk nord for Kongeåen, nu foruden Jacob Appel også Ribes biskop G. Koch, der siden skulle blive konstitueret som midlertidig biskop over de sønderjyske landsdele i overgangstiden 1920-22.

I forfatningsudvalgets forslag findes den første formulering af det ønske, der skulle komme til at vække så stort postyr i Danmark, ønsket om, at den 
endelige sammensmeltning af den sønderjyske kirke og den danske folkekirke skal »forberedes af en menighedsvalgt Kommission der afgiver Betænkning til Regering og Rigsdag «. Ønsket fik sin endelige formulering, da forfatningsudvalgets forslag kom til andenbehandling på det kirkelige udvalgs møde den 26. februar 1919. ${ }^{12}$ Kommissionen, som skulle have til opgave at fremsætte forslag om fælles kirkelove for den danske folkekirke incl. Sønderjylland, ønskedes nu nedsat »af menighedsvalgte Repræsentanter fra hele Danmark, valgt efter lignende Regler som i sin Tid det kirkelige Udvalg«.

Det udvalg, der her henvistes til, var det store kirkelige forfatningsudvalg, der var blevet nedsat ved lov af 15. maj 1903, og som havde siddet $i$ årene 190407. Det var med ønsket om en kirkelig kommission magen til dette udvalg, at Den nordslesvigske Vælgerforenings kirkeudvalg for alvor bevægede sig ind på det kirkelige forfatningsspørgsmål.

\section{Den danske baggrund for ønsket}

Nedsættelsen af Det kirkelige Udvalg af 1903 hang sammen med den demokratisering af folkekirken, som igangsattes efter Systemskiftet, og hvis blivende resultat blev indførelsen af menighedsråd i den danske folkekirke.

Forudsætningerne gik imidlertid helt tilbage til grundloven af 1849 og dens paragraf om, at »Folkekirkens forfatning ordnes ved lov«. Disse ord opfattedes almindeligvis som et løfte til folkekirken om, at den skulle have en forfatning, der ordnede dens styre og forhold til staten. To store kirkekommissioner, nedsat i 1854 og 1868, havde gjort de første forsøg på at opfylde »løfteparagraffen«, med forslag om indførelse af et centralt kirkeråd, der havde en nærmere fastsat kompetence i forhold til Rigsdagen. Ingen af forslagene blev dog vedtaget, og i provisorietiden gik arbejdet med at skaffe folkekirken en forfatning i stå. ${ }^{13}$

Systemskiftet i 1901 satte atter skred i sagen. ${ }^{14}$ I efteråret 1901 fremsatte J.C.Christensen som kirke- og undervisningsminister (kultusminister) et forslag om indførelse af menighedsråd i den danske folkekirke. Ved fremsættelsen gav han udtryk for den opfattelse, at en organisering på menighedsniveau var nødvendig, inden der kunne være tale om at tilvejebringe en samlet kirkeforfatning. Hans forslag vakte stor modstand, dels fordi man opfattede det som et forsøg på at udsætte eller helt skrinlægge indførelsen af en kirkeforfatning, dels fordi der lagdes op til gennemførelse af vigtig lovgivning på det kirkelige område, uden at kirken selv var blevet hørt. Højre og gejstligheden protesterede og krævede nedsættelse af en kirkelig forfatningskommission i stil med de ældre kirkekommissioner. Ved et kompromis mellem Højre og Venstre i 1903 
skete der en sammenkobling af de to ønsker, ønsket om menighedsråd med ønsket om en kirkekommission: Venstre sikrede vedtagelsen af menighedsrådsloven ved at gå med til en samtidig nedsættelse af et stort kirkeligt udvalg, hvortil menighedsrådene skulle vælge halvdelen af medlemmerne, mens den anden halvdel skulle dels vælges af præsterne, dels udpeges af minister, biskopper og universitet. Højre søgte til gengæld at sikre sig ved så at sige at tage menighedsrådsloven som gidsel for kirkeforfatningen: Hvis ikke Rigsdagen inden 1. januar 1910 havde vedtaget det forslag til kirkeforfatningslov, som Det kirkelige Udvalg fik til opgave at udforme, så skulle de nyindførte menighedsråd bortfalde samtidig med ophøret af udvalgets mandat.

Med denne sammenkobling af menighedsrådene på lokalt plan og et valgt kirkeligt udvalg på centralt plan var der skabt en model for en demokratisk forfatningsstruktur, ja, i realiteten var der igangsat et eksperiment med en sådan kirkeforfatning, for Det kirkelige Udvalg fungerede i sin korte virketid faktisk som en slags kirkelig rigsdag. Udvalgets forslag til forfatning for folkekirken gik da også ud på at gøre dette forfatningseksperiment til en permanent forfatningskonstruktion: Ved siden af de lokale menighedsråd skulle der dannes et centralt kirkeråd, sammensat og valgt på stort set samme måde som Det kirkelige Udvalg selv.

Det kirkelige Udvalgs forfatningsforslag lå klar i februar 1907, i god tid inden udløbet af tidsfristen på seks år. Fra Venstres side ønskede man imidlertid ikke at fremsætte udvalgets forslag som lovforslag. Da man nødigt ville se menighedsrådene forsvinde, fremkom man i stedet - så sent som i december 1908, da der kun var et år tilbage af menighedsrådenes levetid - med et forslag om at forlænge menighedsrådsloven indtil den 1.januar 1913. Fra Højres side svarede man, at så ville man også have forlænget loven om Det kirkelige Udvalg. Under de påfølgende forhandlinger viste det sig, at tilhængerne af en kirkeforfatning - $\mathrm{i}$ et forsøg på at redde den grundlæggende kirkeforfatningsmodel - var villige til at indgå et kompromis, der i virkeligheden ikke sikrede stort andet, end at Det kirkelige Udvalg på papiret kom til at fortsætte. Omvendt var kirkeforfatningsmodstanderne så opsatte på at få aflivet den spire til et centralt kirkeråd, der lå i Det kirkelige Udvalg, at de hellere ville lade menighedsrådene afgå ved døden end se udvalget fortsætte. Og det blev resultatet, idet Folketinget forkastede det kompromis, som var forhandlet i stand og allerede vedtaget $i$ Landstinget.

Dermed bortfaldt menighedsrådene - men kun for en kort overgang. I praksis var de blevet uundværlige, ikke mindst fordi J. C. Christensen som kultusminister rent administrativt havde givet rådene den medvirken ved præstevalg, som Højre havde nægtet at tage ind i selve menighedsrådsloven af 1903. Derfor kom der allerede i 1910 et forslag om at indføre menighedsrådene igen. Om 
dette udspandt der sig præcis den samme diskussion som i 1908-09. Højre fremførte igen kravet om, at der ikke måtte indføres menighedsråd undtagen som led i en samlet kirkeforfatning, men nu med endnu mindre respons end forrige gang. Slaget om kirkeforfatningen var allerede tabt. Og ved Jacob Appels menighedsrådslov af 10. maj 1912 fik man så indført permanente menighedsråd - nu med lovfæstet medvirken ved præstevalg - i den danske folkekirke uden nogen tilsvarende etablering af et repræsentativt kirkeligt organ på centralt plan.

\section{Vælgerforeningens reaktion}

At fremsætte ønske om nedsættelse af et nyt kirkeligt udvalg valgt efter samme regler som 1903-udvalget var, som man vil forstå, i en rigsdansk kontekst simpelthen det samme som at hejse kirkeforfatningsfanen på ny. Ikke mindst for den radikale regering i Danmark, der var modstander af enhver tale om en kirkeforfatning, må det have været $\mathrm{i}$ høj grad ubekvemt at se dette ønske fremført fra sønderjysk side i forbindelse med den forestående genforening. Og af samme grund måtte også Den nordslesvigske Vælgerforening være betænkelig ved det ønske, foreningens kirkelige udvalg havde fremsat. Situationen var jo den, at Vælgerforeningens formand, H.P. Hanssen, på daværende tidspunkt arbejdede snævert sammen med den danske regering - så snævert, at han kort efter indtrådte $i$ regeringen som leder af det særlige ministerium for sønderjyske anliggender, der blev oprettet i juni 1919.

$\mathrm{Da}$ indstillingen fra Vælgerforeningens kirkelige udvalg forelå, blev den underkastet en indgående behandling af foreningens ledelse. Det skete på to møder, hvoraf det første fandt sted den 16. april, det andet to uger senere, den 29.-30. april 1919. På disse møder kom det klart til udtryk, at Vælgerforeningen som sådan havde andre interesser at varetage end de kirkelige interesser, der lå bag kirkeudvalgets betænkning.

På det første møde, den 16. april, fremlagde formanden for kirkeudvalget betænkningen, idet han på udvalgets vegne udtrykte ønsket om, »at den maatte gaa over til den danske Rigsdag og det danske Kirkeministerium i uforandret Skikkelse«. H.P. Hanssen takkede som formand for Vælgerforeningen det kirkelige udvalg for dets store arbejde og lovede at imødekomme ønsket på den måde, at kirkeudvalgets betænkning ville blive tilstillet det danske kirkeministerium og den danske rigsdag uforandret, mens Vælgerforeningen så ved siden af ville fremsætte sine særlige synspunkter. Under den påfølgende drøftelse var det især med hensyn til stiftsinddelingen, som hang sammen med grænsedragningsproblemet, og med hensyn til proceduren ved en eventuel af- 
skedigelse af tysksindede præster, at der fra Vælgerforeningens side rejstes indvendinger mod det kirkelige udvalgs betænkning. ${ }^{15}$

Derimod blev der ikke på dette møde gjort bemærkninger til ønsket om nedsættelse af et menighedsvalgt kirkeligt udvalg. At der forelå et problem her, blev H.P. Hanssen imidlertid gjort opmærksom på mellem de to møder. Efter at have modtaget det kirkelige udvalgs betænkning på det første møde sendte han den nemlig privat til den mand, der siden skulle modtage den officielt, kirkeministeren i København. Det nævner Vælgerforeningens forhandlingsprotokol intet om, og der kan næppe være tvivl om, at det må være sket bag ryggen på såvel det kirkelige udvalg som Vælgerforeningens ledelse. At H.P.Hanssen virkelig tog dette usædvanlige skridt, fremgår af et brev, dateret den 25. april 1919, som jeg har fundet i det sønderjyske ministeriums arkiv, og hvori den radikale kirkeminister Th. Povlsen svarer H.P. Hanssen med at give sin mening til kende om betænkningen. ${ }^{16}$ I betragtning af det videre begivenhedsforløb i sagen må indholdet af dette brev siges at være temmelig opsigtsvækkende.

Th. Povlsen indleder med at sige, at han i det væsentlige kan tilslutte sig det kirkelige udvalgs betænkning og derfor ikke har mange bemærkninger at gøre til den. De bemærkninger, han har, går dog netop på de kirkepolitisk helt centrale spørgsmål. Med hensyn til sognerepræsentationen, hvor det kirkelige udvalg havde forudsat, at den eksisterende repræsentation med kirkekollegium og kirkeforstanderskab skulle bibeholdes i den lovordnede overgangstid, idet dog valgretten som i Danmark skulle udvides til også at omfatte kvinder, ser Povlsen langt hellere en indførelse af den danske menighedsrådslovgivning straks: "Var det dog ikke rimeligere, at den her gældende Menighedsraadslov ogsaa indførtes i Sønderjylland med den Indflydelse, den giver Sognemenighederne paa Præstevalget, en Indflydelse, der jo er langt mere vidtrækkende end den, Sognene nu har der«. Skarpest udtrykker kirkeministeren sig imidlertid om betænkningens ønske om nedsættelse af et nyt kirkeligt udvalg: »Punkt C., hvori udtales Ønske om, at der ... nedsættes et kirkeligt Udvalg til at stille Forslag om en fælles Kirkelovgivning, forekommer mig helt overflødigt, idet den fælles Kirkelovgivning jo tænkes gennemført i den lovordnede Overgangstid. Fremsættelsen af et saadant Ønske vil imidlertid volde stor Fortræd her oppe, idet dermed rejses Kampen om en Kirkeforfatning, hvilket dog nødigt skulde ske som Følge af Genforeningen. Jeg henstiller derfor indtrængende, at Punkt C. helt udgaar«.

Der kan ikke være tvivl om, at H.P. Hanssen har modtaget Th. Povlsens brev inden afholdelsen af det andet møde i Vælgerforeningen om det kirkelige udvalgs betænkning den 29. og 30. april, og at brevet har haft betydning for Vælgerforeningens stillingtagen til betænkningen. Det ses især deraf, at der på 


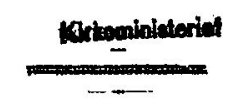

den 25' Apr11 "ar9.

T1l det kirkelige Udvalgs Botankning har jeg 1kke mango Bemmrkninger at gare. I det vesentlige kan jog ylutte mig til den. Jeg maa dog gere opmerksom paa, at allerede 1 den lovoranede overgangat1d finder 1 V1rkeligheden sammensmeltningen med den danske Folkekirke stod, naar danske Kirkeloves Indrorelge 1 apnderjyliand overensstemmende med Udvalgets unske gennemfores. Kun sognereprasontationen ( Ken1ghedgraadene) novnes ikxe af Udvalget, men det forudsøttes, at den nuveronde Reprosentation med k1rkekoliegium 08 Kirke for standerskab gka 1 bibenoldes. Var det dog ikke rimeligere, at don her geldende Kenighedarazdelov ogana Indrortea 1 senderjylland med den Inarlydelse, den giver 3ngnemenlghederne pa Prostovalget, on Indriydelga, der jo er langt mere vidtrækkende ond den, sognenę nu har der. enskes den nuvwrende sognereprasentation beholat umendret, dog med Adgang for kvinder, kan der dog lkke varo noget t1l Hinder derfor, ldot man da kun burde ago dens Inarlydeloe paa Præstevalget, men cen ILghed 1 Lovglimingen, nris onskelighod ellers saa stærkt fremhover af Udvalget, v1lde dog nerved 11 de ot betydeligt skaar.

Punkt c., nvorl udtales onske oln, at der efter den foran omnindlede Lovg cennemrorelse: nodsertes ot k1rkeligt vdvalg til at

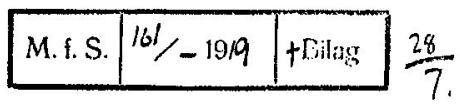

Forste side af kirkeminister Th. Povlsens brev til H.P. Hanssen af 25, april 1919. Det af Valgerforeningen nedsatte kirkelige udvalg fremlagde sin betankning 16. april 1919. Ved Valgerforeningens behandling af betankningen viste der sig på flere punkter uoverensstemmelse mellem udvalgets kirkelige og Valgerforeningens nationalpolitiske interesser. Valgerforeningens formand H.P. Hanssen sendte betankningen til kirkeminister Th. Povlsen inden den endelige behandling $i$ Valgerforeningen. Isar betankningens onske om nedsattelse af et menighedsvalgt udvalg til forberedelse af den kommende kirkelovgivning tog den radikale kirkeminister skarpt afstand fra. Han mente, at det anfagtede Rigsdagens lovgivningsmassige kompetence på det kirkelige område. Kirkeministerens tilkendegivelse fik til folge, at Valgerforeningen lagde afstand til kravet fra det kirkelige udvalg. Rigsarkivet, Det midlertidige Ministerium for de sonderjydske Anliggender, J.nr. 161/1919. 
det andet møde kom forhold frem, som ikke var blevet bragt på bane på det første møde. ${ }^{17}$ Det var til forslaget til ordning af den nordslesvigske kirkes administration under overgangen til dansk styre, at Vælgerforeningen kom med de mest omfattende ændringsforslag. I sit ændringsforslag til punktet om nyvalg til menighedsrepræsentationer og provstisynoder ønskede Vælgerforeningen således, at den gældende kirke- og synodallov allerede i den provisoriske forvaltningstid skulle sættes ud af kraft og erstattes af den danske lov om menighedsråd. Dette såvel som flere andre af ændringsforslagene var helt $\mathrm{i}$ overensstemmelse med ønskerne i Th. Povlsens brev til H. P. Hanssen. Det galder også den lakoniske kommentar, som Vælgerforeningen knyttede til det famøse punkt om en valgt kommission: „Der næres ingen Betænkelighed ved at lade dette Punkt falde bort ${ }^{18}{ }^{18}$

\section{Reaktionen i Danmark}

I overensstemmelse med H.P. Hanssens løfte til det kirkelige udvalg sendtes både udvalgets betænkning og Vælgerforeningens ændringsforslag til den danske regering og rigsdag. Og nu stod man så i Danmark med et tvetydigt budskab fra sønderjyderne: Vælgerforeningens kirkelige udvalg ønskede nedsættelse af en valgt kommission, Vælgerforeningen som sådan nærede ingen betænkelighed ved at lade ønsket bortfalde.

Den sidstnæunte formulering havde klar adresse til den radikale regering. I sit program fra 1905 havde Det radikale Venstre formuleret sin grundlæggende kirkepolitiske holdning, der groft sagt gik ud på selvstyre på menighedsplan og rigsdagsstyre på centralt plan. Det hedder i programmet udtrykkeligt: "Rigsdagens Lovgivningsmyndighed paa det kirkelige Omraade opretholdes ${ }^{19}{ }^{19}$ Med sin formulering gav Vælgerforeningen udtryk for, at den havde fuld tillid til, at den danske rigsdag kunne varetage sin lovgivende myndighed på det kirkelige område, uden at man behøvede at inddrage et særligt kirkeligt organ.

Omvendt havde Vælgerforeningens kirkeudvalg med sit ønske om, at kommende fælles kirkelove for Danmark med Sønderjylland skulle forberedes af et særligt kirkeligt udvalg, implicit givet udtryk for, at det ikke betragtede den danske rigsdag som fuldt kompetent til at lovgive på det kirkelige område. I stedet var det kirken selv, der i form af et repræsentativt valgt kirkeligt udvalg skulle udarbejde forslagene til den kirkelige lovgivning. Et sådant synspunkt måtte vække begejstring i de kredse i Danmark, der ønskede større kirkelig selvstændighed i forhold til staten, eventuelt i form af en egentlig kirkeforfatning. 
Genforeningen i almindelighed og det sønderjyske ønske om et nyt kirkeligt udvalg i særdeleshed kom derfor til at trække de kirkepolitiske fronter op i Danmark. Tilhængerne af en kirkeforfatning så hen til Genforeningen med forventning, mens modstanderne var temmelig bekymrede. For både tilhængere og modstandere udkrystalliseredes henholdsvis forventning og frygt omkring forslaget fra Vælgerforeningens kirkelige udvalg om nedsættelse af et menighedsvalgt udvalg i stil med Det kirkelige Udvalg af 1903. Igennem et sådant udvalg ville forfatningselementer fra den sønderjyske kirke kunne kanaliseres ind $\mathrm{i}$ den danske folkekirke. Ja, man kunne endda forestille sig, at et sådant nyt kirkeligt udvalg selv kunne blive kimen til en kirkeforfatning, såfremt det fik lov at udvikle sig til en mere permanent institution.

Fra højre side af det kirkepolitiske spektrum hilste man følgelig det sønderjyske ønske velkomment. Især inden for Kirkeligt Landsforbund - nærmest en kirkepolitisk kamporganisation dannet under indtryk af Arboe Rasmussensagen - så man straks den kommende genforening som en mulighed for at opnå større kirkelig selvstændighed også i Danmark. Derfor fulgte man nøje de forberedelser til den kirkelige genforening, der foregik i Sønderjylland. Allerede i februar 1919 bragte Landsforbundets blad således en rapport om det sønderjyske kirkeudvalgs arbejde og citerede udførligt fra overvejelserne om forfatningsspørgsmålet. ${ }^{20}$

Men også i bredere folkekirkelige kredse havde man opmærksomheden henledt på genforeningsforberedelserne, og der vedtoges erklæringer til støtte for ønsket fra det sønderjyske kirkeudvalg. Et stort møde, som Kirkeligt Fællesudvalg - der var et fælles udvalg bestående af repræsentanter for Kirkeligt Landsforbund, Kirkeligt Centrum, Indre Mission og en række andre folkekirkelige organisationer - afholdt i Nyborg den 16. og 17.juni 1919, udtalte i en resolution sin tilslutning til det forslag om nedsættelse af en kommission af menighedsvalgte repræsentanter til at forberede fælles kirkelove for Danmark og Sønderjylland, som Vælgerforeningens kirkelige udvalg havde lagt frem i sin betænkning. ${ }^{21} \mathrm{Da}$ Kirkeligt Fællesudvalg atter holdt møde i Nyborg året efter, den 3. og 4. maj 1920, forhandlede man specielt om den kirkelige sammenslutning mellem Sønderjylland og det øvrige Danmark, og redaktør J.M. Kylling fra Haderslev, der havde siddet i Vælgerforeningens kirkelige udvalg, var indbudt til at gøre rede for udvalgets forslag. På mødet vedtog man en resolution til regering og rigsdag, hvori man blandt andet gentog kravet fra mødet året før: »Ligesom i Fjor maa vi kræve, at det sønderjydske Kirkespørgsmaal ikke faar sin endelige Løsning, før et fælles kirkeligt Udvalg af menighedsvalgte Repræsentanter fra Kongeriget og Sønderjylland har faaet Lejlighed til at udtale sig derom ${ }^{22}$ 


\section{Rigsdagens behandling af de sønderjyske ønsker}

Genstand for debat på højeste plan blev tanken om en kommission i den ekstraordinære samling, som Rigsdagen på grund af Genforeningen var nødt til at holde i slutningen af august og begyndelsen af september 1920 .

På dette tidspunkt var den kirkelige genforenings første og anden fase på plads. Allerede i sommeren 1919 havde det danske kirkeministerium påbegyndt forberedelserne til Genforeningen på grundlag af betænkningen fra Vælgerforeningens kirkelige udvalg og i et samarbejde med dette udvalg, det af Rigsdagens partier nedsatte sønderjyske udvalg og det nyoprettede foreløbige Ministerium for sønderjyske Anliggender under ledelse af H.P. Hanssen. Og samme dag, som administrationen af de sønderjyske landsdele overgik fra Den internationale Kommission i Flensborg til de respektive danske ministerier, den 16.juni 1920, havde Rigsdagspartiernes sønderjyske udvalg de første lovforslag på det kirkelige område klar. ${ }^{23}$ I slutningen af juni vedtog Rigsdagen en stor mængde love, der helt eller delvis indførte dansk lovgivning i Sønderjylland, herunder tre love på det kirkelige område. ${ }^{24}$ Som ønsket af Vælgerforeningens kirkelige udvalg gik man således meget hurtigt fra den første provisoriske forvaltningstid, hvor forvaltningen var blevet ordnet rent administrativt, til den lovordnede overgangstid, der skulle komme til at vare indtil 1922.

Den første af de tre love på det kirkelige område gjorde det muligt at udskrive nyvalg til kirkekollegierne og kirkeforstanderskaberne. Samtidig afskaffede den de fem nordslesvigske provstisynoder, men derimod ikke de særlige udvalg under synoderne, der varetog de løbende forretninger. Til disse provstiudvalg skulle der derfor også foretages nyvalg, som ifølge loven skulle ske ved valg af valgmænd, efter at valget af kirkekollegier og kirkeforstanderskaber havde fundet sted. Den anden af de vedtagne love tilsigtede dels at besætte de ledige sønderjyske sognekald, dels at muliggøre udskiftning af præster, som befolkningen måtte ønske at komme af med. Endelig indførte den sidste lov en række grundpiller i dansk kirkelig lovgivning, først og fremmest de kirkelige »frihedslove«, i Sønderjylland. - Fra De radikales side havde man ønsket også loven om udstykning af bortforpagtede præstegårdsjorder indført i Sønderjylland, men det var man ikke kommet igennem med i Rigsdagspartiernes sønderjyske udvalg, ligesom man altså heller ikke havde fået opfyldt Th.Povlsens ønske om en øjeblikkelig indførelse af den danske menighedsrådslov i Sønderjylland.

Indtil videre var forløbet af den kirkelige genforening gennemført i overensstemmelse med de ønsker, der var blevet formuleret af Vælgerforeningens kirkelige udvalg. Og nu var spørgsmålet så, om man også skulle gennemføre 
dette udvalgs forslag om nedsættelse af et menighedsvalgt kirkeligt udvalg til forberedelse af Genforeningens tredje og sidste fase, den endelige sammenslutning af den sønderjyske og den danske kirke.

I tiden mellem afstemningerne i februar og marts og selve Genforeningen i juni 1920 var der som bekendt sket afgørende ting på den politiske arena i Danmark. Efter Påskekrisen fulgte regeringsskiftet den 5. maj 1920, der bragte Venstre til magten og sendte De radikale - og dermed også H.P. Hanssen - ud på sidelinien. Det var ikke mindst dette politiske magtskifte, der var forklaringen på, at de første kirkelove i højere grad stemte overens med ønskerne fra Vælgerforeningens kirkelige udvalg end med den radikale regerings ønsker. Kirkeministeren hed nu ikke længere Th. Povlsen, men J.C.Christensen, og han skulle i sin politik støtte sig på Det konservative Folkeparti, det gamle Højre, der altid havde været positivt over for kirkelige selvstændighedstanker. Derfor var der ikke længere de samme alvorlige hindringer for det sønderjyske kirkeudvalgs ønsker som under den radikale regering før Påskekrisen.

J.C. Christensen forelagde da også et lovforslag om nedsættelse af et menighedsvalgt »Udvalg for kirkelige Anliggender«, der var helt i overensstemmelse med ønsket fra Vælgerforeningens kirkeudvalg, og da forslaget havde tilslutning fra både Venstre og De konservative, var det sikret vedtagelse. Det mødte voldsom modstand hos De radikale og deres politiske allierede, Socialdemokraterne. Modstanden hang ikke sammen med nogen speciel uvilje mod de sønderjyske ønsker, som mødte forståelse og tilslutning fra alle partier, men udsprang af de generelle kirkepolitiske holdninger. Det, som den radikale og socialdemokratiske modstand først og fremmest tog udgangspunkt $i$, var den anfægtelse af Rigsdagens lovgivningsmyndighed, der lå $\mathrm{i}$ ønsket om et særligt kirkeligt udvalg til fremsættelse af de kirkelige lovforslag, og så frygten for, at udvalget skulle udvikle sig til en mere permanent »kirkedag«, en kirkelig parallel til Rigsdagen.25

Det vigtigste argument for nedsættelsen af et nyt kirkeligt udvalg var ganske enkelt, at der var fremsat ønske herom fra sønderjysk side. Under debatten i Rigsdagen hæftede modstanderne af lovforslaget sig derfor også stærkt ved, at Vælgerforeningen som sådan havde taget afstand fra ønsket. I den forbindelse kom man også ind på spørgsmålet, om der fra dansk side var øvet påvirkning på Den nordslesvigske Vælgerforening for at få den til at slette ønsket om en menighedsvalgt kommission fra kirkeudvalgets betænkning.

Påstanden blev fremført allerede under førstebehandlingen af lovforslaget i Landstinget den 26. august 1920. Efter at ordførerne for de fire politiske partier havde tilkendegivet deres mening om lovforslaget, svarede kirkemi- 
nisteren på de rejste spørgsmål og indvendinger. Den radikale ordførers påstand om, at Den nordslesvigske Vælgerforening som sådan ikke ønskede en udvalgsnedsættelse på det kirkelige område, afviste J.C.Christensen. Ønsket om en kommission af menighedsvalgte repræsentanter, valgt efter lignende regler som Det kirkelige Udvalg af 1903, til at fremsætte forslag om fælles kirkelove whar det kirkelige Udvalg for Sønderjylland Gang paa Gang fastholdt overfor Representanter for den danske Rigsdag og fastholder det endnu«. Vælgerforeningen har kun sagt, at den ingen betænkelighed nærede ved at lade dette punkt $i$ kirkeudvalgets betænkning bortfalde. »Men en saadan Udtalelse kan lige saa godt læses paa den Maade, at den heller ingen Betænkelighed har ved at lade det blive staaende. Det er ikke nogen virkelig begrundet Indvending mod det stærke Ønske, der er fremkommet dernedefra, og jeg er endda ikke overbevist om, at ikke denne Bemærkning i den nordslesvigske Vælgerforenings Betænkning skyldes Ønsker heroppefra, som har haft Indflydelse dernede ${ }^{26}$

Ved førstebehandlingen i Folketinget den 7.september 1920 kom man igen ind på spørgsmålet, nu med flere detaljer. Den konservative ordfører, kirkehistorieprofessoren J.Oskar Andersen, tillagde det ikke megen vægt, at Vælgerforeningen som sådan ikke havde fastholdt ønsket om et nyt kirkeligt udvalg. Ligesom kirkeministeren var han tilbøjelig til at mene, »at Vælgerforeningen har taget denne Stilling væsentlig under Paavirkning fra dansk Side, fra en bestemt politisk Lejr ...«. ${ }^{27}$ På trods heraf gentog De radikales ordfører i sin første tale partiets standpunkt fra landstingsbehandlingen, at sønderjyderne ikke havde ønsket et kirkeligt udvalg som det foreslåede. Han fastholdt, at man ikke kunne gøre ønsket om et udvalg til et udtryk for sønderjydernes mening som sådan, når Vælgerforeningens egentlige kompetente forsamling havde udtalt sig, som den havde. ${ }^{28}$

Så blev debatten personlig - for den radikale ordfører var ingen ringere end den forhenværende kirkeminister selv! J. Oskar Andersen svarede Th. Povlsen, at Vælgerforeningens frafald fra det ønske, som foreningens kirkelige udvalg havde udtalt, meget muligt skyldtes påvirkning fra rigsdansk side - han kunne f.eks. tænke sig påvirkning fra Povlsen selv. ${ }^{29}$ Th. Povlsen fandt, at det var en fornærmelse mod Vælgerforeningen at mene, at den ikke skulle kunne tage selvstændigt stilling ud fra sin overbevisning - men i øvrigt indrømmede han, at der også efter hans mening havde været tale om påvirkning. Han kunne f.eks. nævne regeringens egen undervisningsminister, Jacob Appel, som en mand, der havde søgt at påvirke Vælgerforeningens stillingtagen: „Da Forslaget fremkom fra det kirkelige Udvalg dernede, var han fuldkommen enig med mig om, at dette Punkt var et betænkeligt Punkt, og at det var ønskeligt, om der kunde blive taget Afstand derfra ${ }^{30}$ 


\section{Spørgsmålet om påvirkning fra dansk side}

Allerede i samtiden var man således klar over, at der var øvet påvirkning fra rigsdansk side for at få Vælgerforeningen til at frafalde kravet om et nyt kirkeligt udvalg, og efter fundet af Th. Povlsens brev til H.P. Hanssen af 25. april 1919 kan der da heller ikke herske nogen som helst tvivl herom.

Derimod er det påfaldende, at ingen synes at have overvejet muligheden af påvirkning fra den modsatte side af det kirkepolitiske spektrum på Vælgerforeningens kirkelige udvalg, da dette formulerede sit ønske om en valgt kirkekommission.

Jeg kan desværre ikke fremlægge sikre beviser for påvirkning fra højrekredse i den danske folkekirke på Vælgerforeningens kirkelige udvalg af samme art som Th. Povlsens brev til H.P. Hanssen. Det er tænkeligt, at der vil kunne findes sådanne beviser i privatbreve fra datiden, men så langt ned i detaljer med denne sag har jeg ikke haft mulighed for at gå. Derimod kan jeg fremføre en række indicier, der til sammen forekommer mig at være stærke nok til at bære synspunktet:

For det første var de 15 medlemmer af Vælgerforeningens kirkelige udvalg almindelige sognepræster og kirkeligt engagerede lægfolk fra Nordslesvig, som klart nok ikke havde større viden om danske kirkelige forhold; netop derfor sørgede de hele tiden for at tage kontakt til folk nord for Kongeåen for at indhente den nødvendige information.

For det andet var der tale om, at disse 15 sønderjyder fremsatte et forslag, der forudsatte et intimt kendskab til den kirkelige lovgivningsproces i Danmark, ja, i virkeligheden til hele forfatningsdebatten i den danske folkekirke tilbage til grundloven af 1849 .

For det tredje konsulterede Vælgerforeningens kirkelige udvalg faktisk personer i Kongeriget, der var centralt placeret i dansk kirkepolitik. Jacob Appel er nævnt flere gange i udvalgets forhandlingsprotokol, men han kan dog ikke tænkes at have påvirket sønderjyderne til at rejse ønsket om et nyt kirkeligt udvalg, for han stod ligesom en del andre Venstremænd rent kirkepolitisk for synspunkter, der lå meget tæt på De radikales - således som det også fremgår af Th. Povlsens udsagn i Folketinget om enigheden mellem ham og Appel. Derimod er biskop G. Koch i Ribe oplagt som kandidat, når man spørger, hvem der kan have fået ideen til ønsket om et nyt kirkeligt udvalg: Koch havde nemlig selv siddet i Det kirkelige Udvalg af 1903, hvor han havde været en ivrig fortaler for en demokratisk kirkeforfatning.

Når jeg i min redegørelse for arbejdet i Den nordslesvigske Vælgerforenings kirkelige udvalg har understreget alle vidnesbyrd om kontakter mellem udvalget og danske kredse i den allerførste fase af genforeningsprocessen, hænger 


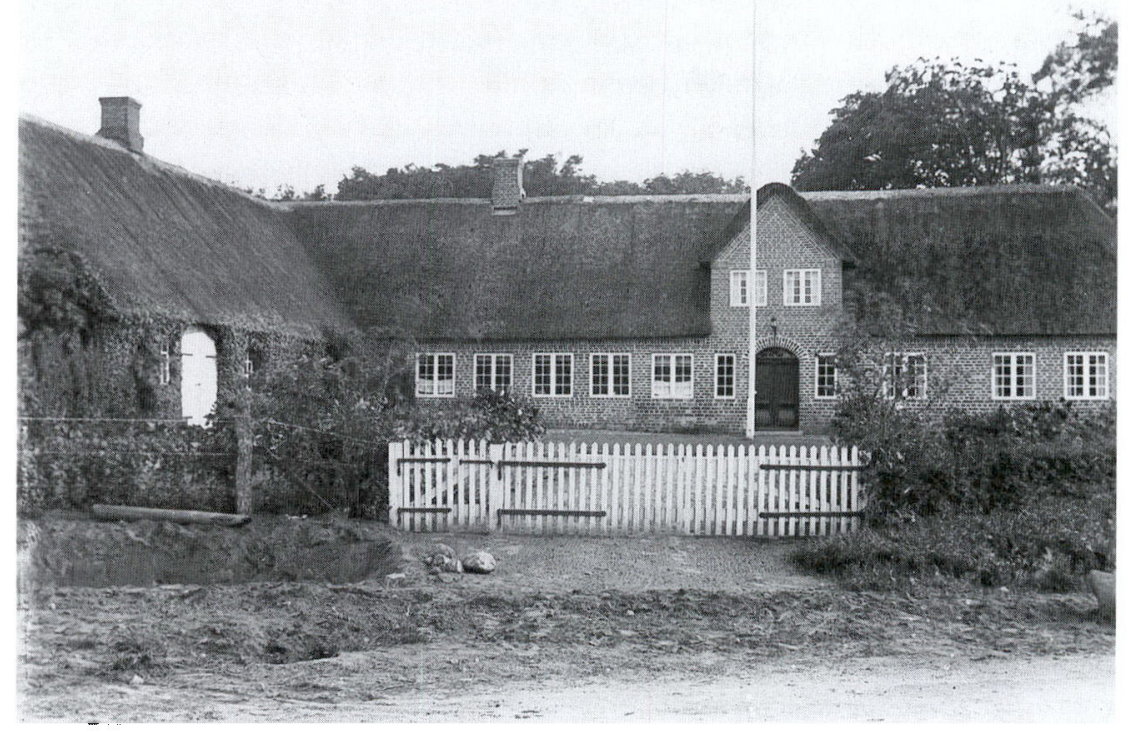

Visby prastegård, Tonder provsti. Ved det store kirkelige lovkompleks af 1922 styrkedes det kirkelige selvstyre. På det okonomiske område betod de nye love, at den sonderjyske kirkes relativt store okonomiske selvstandighed fortes over på hele den danske folkekirke. Frentover fik menighedsrådene langt storre indfydelse end for på okonomiske sporgsmål, som f.eks. afhandelse af prastegårdsjorder. Foto af C. C. Biehl fra 1920 'erne, Institut for sonderjysk Lokalhistorie.

det sammen med, at den specifikke henvisning til et 15 år gammelt dansk udvalg efter min mening umuligt kan være noget, sønderjyderne selv har fundet på. Der må være tale om et forslag hvisket sønderjyderne i øret fra kirkelige kredse i Danmark.

Jeg finder denne formodning bestyrket af et fjerde og sidste indicium, nemlig den måde, hvorpå man i Sønderjylland forholdt sig i forbindelse med valgene til det nye kirkelige udvalg i vinteren 1920-21. Pointen ved at have et valgt udvalg og ikke blot en ministerudpeget kommission var, at man derved kunne få de forskellige kirkelige retninger repræsenteret i forhold til deres aktuelle styrkeforhold. Det var særdeles vigtigt i Danmark, med det stærke retningspræg, som dansk kirkeliv havde, og reglerne for valgene til Det kirkelige Udvalg af 1903 var da også omhyggeligt blevet udformet under hensyntagen hertil, idet der opereredes med forholdstalsvalg mellem forskellige lister. Denne problemstilling savnede imidlertid enhver relevans i Sønderjylland, og derfor ser man da også, at der ved valgene her $i$ høj grad var tale om fredsvalg. Til valget af læge medlemmer til det kirkelige udvalg indkom der kun én kandidat- 
liste, som netop indeholdt det antal kandidater, der skulle vælges, således at de på listen opførte personer simpelthen blev erklæret for valgt uden stemmeafgivning. Ved valget af præster lignede forholdene ved første øjekast mere situationen i Kongeriget, idet der her indkom tre kandidatlister. Ser man nærmere efter, viser det sig imidlertid, at de tre lister med tre navne på hver til sammen kun indeholder fire forskellige navne! Listerne havde forskellige spidskandidater, men var ellers omtrent identiske. ${ }^{31}$

\section{Afslutning}

Hvis det virkelig var danske kredse, der med kirkepolitiske bagtanker bragte forslaget om et nyt kirkeligt udvalg ind i det sønderjyske kirkeudvalgs betænkning, således som jeg her har argumenteret for det, så spillede de hasard med sønderjydernes interesser. Der kan næppe være tvivl om, at ønsket om et nyt kirkeligt udvalg kom til at betyde en unødig komplicering af den kirkelige genforeningsproces. Af forskellige grunde, først og fremmest regeringsskiftet efter Påskekrisen i 1920, der satte De radikale fra magten, gik det imidlertid ikke så galt, som det kunne være gået. I det store politiske drama, som Genforeningen udartede til, forblev de kirkepolitiske uenigheder en brik af mindre betydning.

Noget stort skridt i retning af en kirkeforfatning kom Genforeningen i øvrigt ikke til at betyde. Ved lov af 10 . september 1920 fik man nedsat det kirkelige udvalg, der var ønsket fra sønderjysk side. Kirkeforfatningsspørgsmålet var oppe at vende ved de indledende drøftelser i udvalget og stak også hoven frem under diskussionerne om bispevalg og om indførelse af nye menighedsrepræsentationer, enten provstiudvalg eller stiftsudvalg, men nogen dominerende rolle kom det ikke til at spille. Netop på baggrund af hele det politiske røre omkring nedsættelsen holdt J. C. Christensen udvalget i stramme tøjler, og der var tilsyneladende også i udvalget selv enighed om, at den kirkelige genforening ikke måtte obstrueres af kirkeforfatningsspørgsmålet. ${ }^{32}$

Efter et års koncentreret arbejde var udvalget klar med de ni udkast til lovforslag, der blev til kirkelovene af 1922. Selv om regeringens fremsættelse af udvalgets lovforslag kom til at give anledning til protestmøder og endda et mindre »oprør« inden for Venstres egne rækker, kan resultatet af udvalgets arbejde ikke karakteriseres som særlig skræmmende for modstanderne af en kirkeforfatning. ${ }^{33}$ Indførelsen af bispevalg blev i datiden set som et skridt $\mathrm{i}$ retning af en kirkeforfatning, men reelt var menighedsvalgte biskopper blot et led $\mathrm{i}$ den almindelige demokratisering af kirken - og under alle omstændigheder havde de intet med påvirkning fra den sønderjyske kirke at gøre. Her 
var det, der opnåedes for de kirkelige selvstændighedsbestræbelser, ikke en følge af Genforeningen, men et resultat af den nye politiske alliance mellem Venstre og Det konservative Folkeparti, der gav De konservative en indflydelse på dansk kirkepolitik, de ikke havde haft før. Nye organer for menighedsindflydelse af synodalt tilsnit blev der ikke tale om i kirkelovene - med én enkelt undtagelse: Inspireret af de sønderjyske forhold indførte man provstiudvalg, men man sørgede samtidig omhyggeligt for at begrænse deres funktioner til det rent økonomiske, således at de blot blev en slags kontrolinstans med menighedsrådenes økonomiske forvaltning.

I historien om den moderne folkekirkeordnings tilblivelse spiller Genforeningen en betydelig rolle. Der er dog i højere grad tale om, at Genforeningen blev anledning til kirkelovene af 1922, hvormed man satte slutstenen på den kirkelige demokratiseringsproces, der var indledt i 1901, end om at den sønderjyske kirkes forfatningsmæssige stilling faktisk kom til at inspirere til grundlæggende ændringer af den danske folkekirkes styre. Det økonomiske var det eneste område, hvor man virkelig bøjede de danske kirkeforhold i retning af de sønderjyske, idet menighedsrådene efter de nye kirkelove fik langt større ansvar for sognets økonomi end tidligere. På dette ene punkt skulle forholdene i Sønderjylland gennem Genforeningen komme til at sætte sig varige spor i den danske folkekirkes administration.

\section{NOTER}

Artiklen udspringer af mit arbejde med folkekirkeordningens tilblivelse 1901-22 inden for rammerne af det projekt om den danske forvaltnings historie, som Statens Humanistiske Forskningsråd igangsatte i 1990, og som jeg var tilknyttet som stipendiat 1991-92. Redegørelsen bygger i hovedsagen på det utrykte kildemateriale vedrerende den kirkelige genforening, der findes i Kirkeministeriets og det sønderjyske ministeriums arkiver i Rigsarkivet og i Den nordslesvigske Vælgerforenings arkiv i Landsarkivet for Sønderjylland. Dertil kommer de trykte referater af forhandlingerne på Rigsdagen og i det særlige sønderjyske udvalg, som Rigsdagens partier nedsatte for at forberede Genforeningen.

1. Se P.G. Lindhardt, »Tiden 1901-1965«, Den danske Kirkes Historie VIII, København 1966, især s. $39-44,67-73,108-124$.

2. P. Severinsen, Folkekirkens Ejendoms-Historie, København 1920. Bogen, der giver en historisk fremstilling af ejendomsretten til kirkegodset i Danmark, med et særligt kapitel om forholdene $i$ Sønderjylland, er skrevet som indlæg i den datidige debat om spørgsmålet.

3. »Frihedslovene« var loven om sognebåndsløsning af 1855 , loven om valgmenigheder af $1868 \mathrm{og}$ loven om kirkers brug af 1872 . Se om disse love og deres baggrund P.G. Lindhardt, "Tiden 18491901«, Den danske Kirkes Historie VII, København 1958, især s. 31f, 135-140. Med hensyn til menighedsrådslovgivningens tilblivelse henvises til P.G. Lindhardt, "Tiden 1901-1965«, Den danske Kirkes Historie VIII, København 1966, især s. 18-31.

4. Den bedste fremstilling af de sønderjyske kirkeforhold i perioden 1864-1920 findes i Valdemar Ammundsen, "Det aandelige Liv«, Sonderjyllands Historie V, København 1932-33, s. 305-410. En generel behandling af de kirkelige forfatningsforhold i Tyskland på denne tid gives i J. Oskar Andersen, Kirkeorganisation udenlands, København 1905, s. 44-64. 
5. Ved præsteudnævnelser i Sønderjylland var forholdet normalt det, at konsistoriet i Kiel, den egentligt styrende myndighed i den slesvig-holstenske landskirke, udnævnte hveranden gang, mens menigheden hveranden gang valgte mellem tre af konsistoriet præsenterede kandidater, efter at disse havde haft lejlighed til at holde en prøveprædiken. Ifølge den danske menighedsrådslov af 1912 skulle præsteudnævnelser foregå på den måde, at menighedsrådet fik tilstillet samtlige indkomne ansøgninger til et ledigt præsteembede og derefter indstillede tre, som Kultusministeriet (fra 1916: Kirkeministeriet) så kunne vælge iblandt, idet ministeriet dog var bundet til at udnævne en ansøger, som ved første afstemningsrunde $i$ rådet havde fåt samtlige stemmer.

6. Betænkning fra "Det kirkelige Udvalg«, nedsat af "Den nordslesvigske Vælgerforening« i Anledning af Genforeningen med Danmark 1919, optrykt i Beretning fra det $i$ Henhold til Lov af 10. September 1920 nedsatte Udvalg for kirkelige Anliggender, København 1922, s. 17-29, citat fra s. 27.

7. Kun et enkelt af problemerne er tidligere behandlet, nemlig spørgsmålet om de fremtidige forhold på kirkens område for det tyske mindretal. Se Henrik Becker-Christensen, Dansk mindretalspolitik $i$ Nordslesvig. Udformningen af den danske politik over for det tyske mindretal 1918-20, Aabenraa 1984, især s. 216-224.

8. Det følgende bygger dels på oplysningerne i udvalgets betænkning af 16. april 1919 (se note 6), dels på forhandlingsprotokollen for udvalget i Vælgerforeningens arkiv i Landsarkivet i Aabenraa. Se generelt Henrik Becker-Christensen, Dansk mindretalspolitik $i$ Nordslesvig. Udformningen af den danske politik over for det tyske mindretal 1918-20, Aabenraa 1984, s. 189-200.

9. Landsarkivet for de sønderjyske landsdele, Valgerforeningen for Nordslesvig. Forhandlingsprotokol for det kirkelige Udvalg 1918-20 (nr. 33), s. 7-9.

10. Jeg går ud fra, at der menes det udvalg, der også kendes som »Udvalget for den sønderjyske kirkesag«. Jf. Margrethe Christiansen, Jacob Appel. En mand og hans arv, København 1970, s. 268-271.

11. Landsarkivet for de sønderjyske landsdele, Valgerforeningen for Nordslesvig. Forhandlingsprotokol for det kirkelige Udvalg 1918-20 (nr. 33), s. 10-13.

12. Landsarkivet for de sønderjyske landsdele, Vælgerforeningen for Nordslesvig. Forhandlingsprotokol for det kirkelige Udvalg 1918-20 (nr. 33), s. 14-22.

13. H.J.H. Glædemark, Kirkeforfatningssporgsmaalet i Danmark indtil 1874. En historisk-kirkeretlig Studie, København 1948; Steen Skovgaard Andersen, "Kirkeforfatningsspørgsmålet 1848-1901 «, Kirkehistoriske Samlinger 1992, s. 147-208.

14. Se for det følgende Per Ingesman, »Kirkeforfatning, menighedsråd eller præstevalg. Alternativer i den folkekirkelige demokratiseringsproces 1901-22«, Forvaltningshistorisk antologi, red. Helle Blomquist og Per Ingesman, København 1993, s. 209-228. Specielt om Det kirkelige Udvalg af 1903 se Carl Trock, »Stod kirkeforfatningen for døren? Om det kirkelige udvalg 1904-07«, Dansk teologisk Tidsskrift 1955, s. 105-122, 149-173.

15. Landsarkivet for de sønderjyske landsdele, Vælgerforeningen for Nordslesvig, Forhandlingsprotokol for bestyrelses- og tilsynsrådsmøder 1908-21 (nr. 3). Bestyrelses- og tilsynsrådsmøde 16/4 1919.

I øvrigt blev der fra Mellemslesvig anket over, at betænkningen kun havde taget hensyn til Nordslesvig. Denne kritik førte til, at der på det følgende møde nedsattes et særligt Kirke- og Skoleudvalg for Flensborg og Mellemslesvig.

16. Brev fra kirkeminister Th. Povlsen til fhv. rigsdagsmand H.P. Hanssen, dat. 25/4 1919, i Rigsarkivet, Det midlertidige Ministerium for de sønderjydske Anliggender, J.nr. 161/1920. At brevet ligger i dette arkiv, skyldes naturligvis, at H.P. Hanssen har taget det med til København, da han kort efter blev minister for sønderjyske anliggender og skulle til at forberede Genforeningens praktiske gennemførelse.

17. Landsarkivet for de sønderjyske landsdele, Vælgerforeningen for Nordslesvig, Forhandlingsprotokol for bestyrelses- og tilsynsrådsmøder 1908-21 (nr. 3). Bestyrelses- og tilsynsrådsmøde 29-30/4 1919.

18. Udvalgets betænkning med Vælgerforeningens ledsagende kommentarer findes optrykt i Beretning fra det $i$ Henhold til Lov af 10. September 1920 nedsatte Udvalg for kirkelige Anliggender, København 1922, s. 17-29. 
19. Det radikale Venstres Program vedtaget 20.-21. Maj 1905, her efter Det sønderjydske Spørgsmal, udg. af Det radikale Venstre, 1920, s. 4-6.

20. C. J. Holt, "Fra Sønderjylland«, Kirkeligt Landsforbund 1919, nr. 1, s. 6-8.

21. Referat fra mødet i C. J. Holt, »Det kirkelige Forhandlingsmøde i Nyborg 16. og 17. Juni«, Kirkeligt Landsforbund 1919, nr. 7, s. 52f.

22. "Det kirkelige Fællesudvalgs Møde paa Nyborg Strand 3. og 4. Maj 1920«, Kirkeligt Landsforbund 1920 , nr. 6 , s. $43-48$, se s. $45 f$.

23. Se først og fremmest den fortrolige udgave af Forhandlinger $i$ Rigsdagspartiernes sonderjydske Udvalg. 1919-20. Forhandlingerne om de kirkelige spørgsmål kan findes via registret over lovforslag s. XV-XXV (lovforslag nr. 12, 13, 24, 43).

24. Med hensyn til lovforslagene og Rigsdagens behandling af dem se Rigsdagstidende 1919-20, Tillæg A, sp. 6979-6986, 6987-6996, 6997-7000; Forhandlinger i Folketinget sp. 6227f, 624lf, 6341-46, 6403f, 6434f; Forhandlinger i Landstinget sp. 2279-2281, 2305f, 2313, 2314, 2319, 2326; Tillæg C, sp. 2129-2132, 2133-2140, 2141-2142, 2459-2462. De vedtagne love findes i Love og Ekspeditioner vedkommende Kirke- og Skolevasen 1919-1920, s. 677-679, 680-685, 685f, jf. nogle præciseringer senere på året s. 887-889 og 933f.

25. Med hensyn til lovforslaget og Rigsdagens behandling af det se Rigsdagstidende overordentlig samling 1920, Tillæg A, sp. 1-6; Forhandlinger i Landstinget sp. 8, 9-12, 62-88, 97, 106-130, 130f; Forhandlinger i Folketinget sp. 574, 575, 579-616, 664-667, 684f; Tillæg B, sp. 19-24; Tillæg C, sp. 75-78, 87-88.

26. Rigsdagstidende overordentlig samling 1920, Forhandlinger $\mathrm{i}$ Landstinget, sp. 73-80.

27. Rigsdagstidende overordentlig samling 1920, Forhandlinger i Folketinget, sp. 595.

28. Smst., sp. 603, 613.

29. Smst., sp. $614 \mathrm{f}$.

30. Smst., sp. 615 .

31. Rigsarkivet, Kirkeministeriet, 1. ekspeditionskontor, Journalsager. J.nr. 3 U 2595.

32. Referater af udvalgets møder findes i Rigsarkivet, Kirkeministeriet, Institutioner under Kirkeministeriet, Det $i$ henhold til lov nr. 513 af 10 . september 1920 nedsatte udvalg for kirkelige anliggender (»Kirkeligt Udvalg () 1920-21. Resultaterne af udvalgets arbejde foreligger i Beretning fra det $i$ Henhold til Lov af 10 . September 1920 nedsatte Udvalg for kirkelige Anliggender, København 1922.

33. Se om 1922-lovenes tilblivelse og debatten om dem J.Oskar Andersen, Kirkelovene og deres Forhistorie, København 1922; P. G. Lindhardt, »Tiden 1901-1965«, Den danske Kirkes Historie VIII, København 1966, s. 128-135; Niels Kjær, Baggrunden for, debatten om og betydningen af kirkelovene af 30. juni 1922. Et bidrag til belysning af forholdet mellem stat og kirke i Danmark $i$ det 20. \&rhundrede, Emnekreds i kirkehistorie, Det teologiske Fakultet, Aarhus Universitet 1975 (duplikeret). 